\title{
Increasing the Potential for Reuse and Recycling of Construction and Demolition Waste - A Case Study From Ireland
}

\author{
Rosemary Byrne ${ }^{1} \&$ Bernadette O’ Regan ${ }^{1}$ \\ ${ }^{1}$ Centre for Environmental Research, Department of Chemical and Environmental Sciences, University of \\ Limerick, Ireland \\ Correspondence: Bernadette O' Regan, Centre for Environmental Research, Department of Chemical and \\ Environmental Sciences, University of Limerick, Ireland. Tel: 353-6120-2552. E-mail: Bernadette.ORegan@ul.ie
}

\author{
Received: September 3, 2014 Accepted: October 17, 2014 Online Published: November 5, 2014 \\ doi:10.5539/enrr.v4n4p245 URL: http://dx.doi.org/10.5539/enrr.v4n4p245
}

\begin{abstract}
Ireland reports high levels of construction and demolition waste (C\&DW) recycling, yet has conducted little research into the use of recycled aggregates. This study examines whether recycled aggregate can offer a viable alternative to the use of natural aggregate in concrete production.

The options available for the use of C\&DW in Ireland are investigated together with the effect of recycled aggregate on concrete properties. The environmental impact of extracting and processing natural aggregates is compared to that of recycling aggregate, as are the cost and relative difficulties of reprocessing C\&DW for re-use.

There is little incentive for the use of recycled aggregate in Ireland. It is not without environmental impact and the long-term durability effects on concrete are still relatively unknown. The material can provide a cost effective alternative to natural aggregate. Recycled aggregate is highly suitable for use in pre-cast concrete products where problems associated with ready-mixed concrete use are not an issue. Retained cementitious properties of the material can also be used to good effect in road construction. Designing concrete with end of life and reuse potential in mind may further increase acceptance of the material.

Recycled aggregate use in Ireland lags behind many other European countries, further difficulties may be experienced in gaining acceptance for a largely untested material in light of the recent pyrite controversy. This study may open the way for future research into greater use and the way in which policy could be utilised to fund such research and promote adoption of the material.
\end{abstract}

Keywords: resource management, environmental impacts, construction and demolition waste, construction materials

\section{Introduction}

Following the collapse of the Irish construction sector in 2008, there remained almost 3,000 unfinished or unoccupied housing developments across Ireland. While much work has been done in the intervening years to resolve this problem, by 2012 approximately 1,100 developments were deemed to be in a seriously problematic condition (Housing Agency, 2013; Housing Agency, 2012). In the years prior to this, some half a million new homes were built, peaking in the year 2006 with the construction of 22 houses per thousand population (Figure 1). The average European housing construction rate at that time was approximately 5.3 per thousand (Central Statistics Office [CSO], 2008). This over-development resulted in a pattern of surplus housing located largely in the more rural midlands and borders areas (Kitchin et al., 2010), whereas, it is expected that the greater requirement for housing in the near to medium future will predominantly occur in the larger urban areas and in the more densely populated Eastern half of the country (CSO, 2013; Finnegan, Maloney, \& Duffy, 2012).

The Irish Government policy is for the reuse of existing buildings being given priority over new-build construction (Department of the Environment, Heritage and Local Government [DoECLG], 2011), so that there is a need where possible to refurbish empty housing and to complete rather than demolish the unfinished housing developments. However, the Department of the Environment stated that the most prudent policy may be to demolish the buildings as the developments appear unviable in both the short and long term due to their location, build quality and lack of commercial demand, (Housing Agency, 2012). This was followed with the announcement of the intention to clear 40 development sites in 2014 (Housing Agency, 2013). 

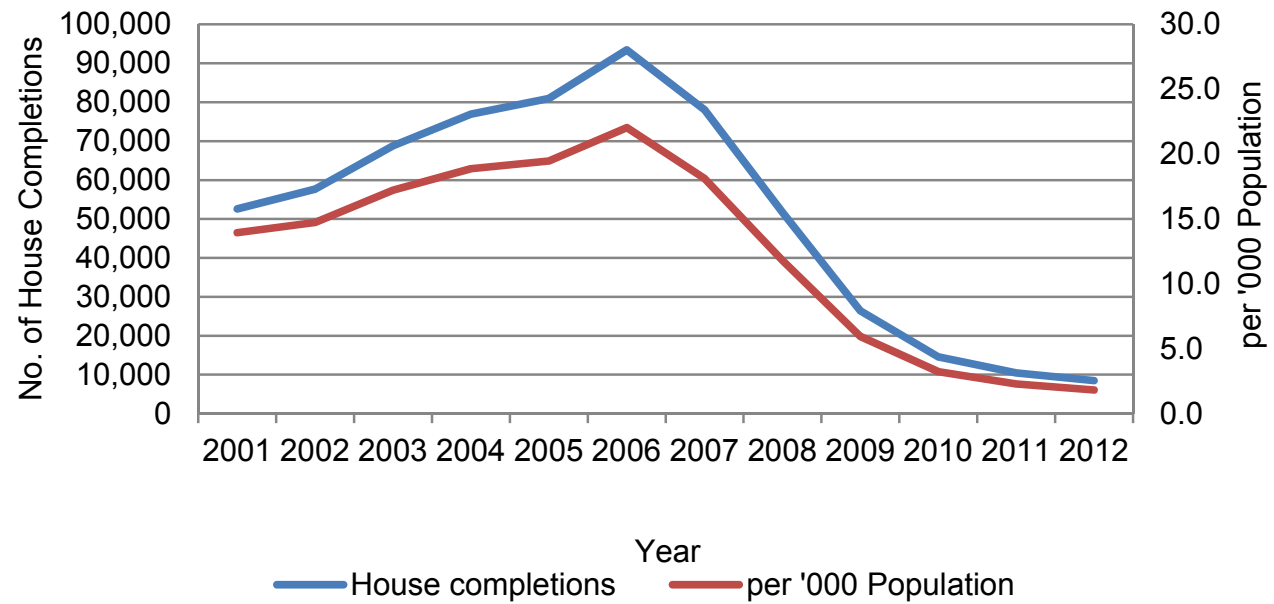

Figure 1. House Completions 2001-2012 (Source: Construction Industry Federation (CIF), 2013; Statistics Population, 2013)

\subsection{Wasted Resources}

According to the European Aggregates Association, the construction of an average home requires up to 400 tonnes of aggregate (European Aggregates Association [UEPG], 2012) and although the exact number of houses in these problem developments is unknown, there are currently over 30,000 unoccupied or unfinished dwellings with no activity on site (Housing Agency, 2012). The possible demolition of these properties represents the potential waste of tens of millions of tonnes of natural aggregate resources, including the environmental impact of the manufacture and transportation of these goods.

\subsection{Recycled Aggregate}

Recycled aggregates are produced from reprocessing inorganic material previously used in a construction process, which includes crushed concrete from construction and demolition waste (C\&DW). Recycling waste concrete into aggregates is considered to be more sustainable than the extraction, processing and transportation of natural aggregate (Ready Mixed Concrete - Introduction, 2012; Sustainable Aggregates, 2013; Mineral Products Association [MPA], 2011). With the quality of recycled aggregates from demolition improving, many countries across Europe, whether through a lack of landfill space, availability of natural materials or for environmental benefit, use recycled aggregate in construction products, with some countries specifying that recycled aggregate must be used in publicly funded works (UEPG, 2012).

In Ireland, the use of additional cementitious materials and efforts to reduce the environmental impact of cement production have been well publicised, and awareness among concrete specifiers and manufacturers of the benefits to be gained from improved environmental performance is increasing (Sustainable Development, 2013; Environmental - Overview, 2013). With few exceptions, the use of recycled aggregates in the production of ready-mixed concrete has received little attention, with the material used predominately for infrastructure projects (Ready Mixed Concrete - Introduction, 2012).

There has been little research into the use of recycled aggregates in Ireland and while there have been many studies conducted elsewhere, these have tended to concentrate on one aspect of the material's technical, environmental or economic performance, whereas, this study examines all three elements to determine if the use of recycled aggregate could be feasible in a commercial operation. This study may open the way for future research into greater use of recycled aggregate in Ireland and into the way in which future taxation policy could be utilised to promote and benefit resource management and greater sustainability within the construction materials supply sector.

\section{Objectives and Methodology}

There has been little research into the use of recycled aggregates in Ireland and while there have been many studies conducted elsewhere, these have tended to concentrate on one aspect of the material's technical, environmental or economic performance. This study examines all three elements to determine if the use of recycled aggregate could be feasible in a commercial operation. This study may open the way for future research into greater use of recycled aggregate in Ireland and into the way in which future taxation policy could be utilised to promote and benefit resource management and greater sustainability within the construction materials supply sector. 
This study examines previously published studies and reports, together with the experiences of those in industry, to compare recycled aggregate derived from $C \& D W$ and natural aggregate to determine if recycled aggregate could offer a viable alternative for use in the production of ready-mixed concrete In Ireland.

This is done by:

- investigating the options available for the use of construction and demolition waste,

- examining the effect of using recycled aggregate on the properties of concrete,

- comparing the environmental impact of producing natural aggregates to that of recycling aggregate, and

- comparing the cost and relative difficulties of reprocessing construction and demolition waste for re-use as aggregate to the extraction and processing of virgin material.

The project involved a desktop study of literature and reports, requests for information and/or assistance from companies and individuals involved in: construction material supply, demolition and recycling industries, government agencies and industry bodies. Approximately one quarter of those contacted responded with information. Of those responses, follow up phone calls/interviews were conducted.

\section{Construction and Demolition Waste in Ireland}

Legislation governing the management of waste from construction and demolition projects in Ireland comes under the Waste Management Acts 1996-2011, which are enforced for example through the Waste Management (Licensing) Regulations 2011, Waste Management (Collection Permit) Regulations 2008 and the Waste Management (Landfill Levy) Amendment Regulations 2012 (Waste Mgmt Acts, 2013; Waste Licensing \& Permitting, 2013).

In 2002, the National Construction and Demolition Waste Council (NCDWC) was established as a voluntary construction industry initiative to promote best practice in waste prevention, reduction, reuse and recycling in construction and demolition projects. The council was also required to provide a framework for achieving compliance with the Irish government requirement for increasing the recycling of C\&DW from a target of $50 \%$ in 2003 to $85 \%$ by 2013 (Voluntary Construction Industry Initiative, 2013). Best practice guidelines for the preparation of waste management plans for construction and demolition projects in both the public and private sectors were published in 2006. The council has been largely inactive since 2008, as many members have left the industry and/or the organisations they represent are no longer operational.

\subsection{Demolition Process}

While every demolition project is different, the decision on the process to be used depends on space, time available and on costs, as it is more economical to first knock a building and then segregate the waste. Depending on the individual job or client, demolition projects may have a specification for both the demolition works to be carried out and the recovery and recycling of materials. While the types and quantities of materials used in the construction of a housing development vary considerably depending on the size, style, construction method and quality of build, Table 1 details estimated tonnages of materials containing aggregate in a three bedroom house, which could be recovered to produce recycled aggregate. The cost of demolition can be considerable; Table 2 provides the estimated demolition costs per cubic metre of a typical three bedroom semi-detached house in Ireland. These costs do not include waste separation and treatment.

Table 1. Estimated Tonnages and Volume of Material (Source: Carroll O'Keeffe; Duggal, 2012)

\begin{tabular}{cccccc}
\hline Material & General Fill & Concrete & Block and Brick & Roof Tiles & Total \\
\hline Tonnes & 60 & 125 & 179 & 4 & 368 \\
$\mathrm{M}^{3}$ equiv. & 38 & 52 & 100 & 3 & 193 \\
\hline
\end{tabular}

Table 2. Volumetric Calculation of Demolition Costs (Source: Padraig Arthur \& Associates)

\begin{tabular}{ll}
\hline Element & $€ / \mathrm{m}^{3}$ \\
\hline Concrete roof tiles & 3.50 \\
Roof Trusses & 2.80 \\
Blocks and Bricks & 60.00 \\
Timber first floor construction and first floor timber partitions & 2.70 \\
Ground Floor concrete and concrete paths & 10.00 \\
Sub floor hard-core filling & 12.00 \\
Concrete in foundations & 9.00 \\
External block / brick boundary walls & 30.00 \\
\hline
\end{tabular}


It is estimated that it is possible to recover and recycle $95-98 \%$ of demolition waste in Ireland. If a building contains salvageable materials such as doors, windows, plumbing and sanitary ware or if space is limited, for example in a city centre, a building will usually be soft stripped to remove as much material as possible before demolition. If these salvaged materials have a market value, they may be reused. Timber and metals are removed and passed to specialist recyclers depending on distance from the facility. Metals are segregated for specialist recovery abroad, while timber, when conditions allow, is reused in Ireland (Metals Recycling, 2013). Remaining mixed waste is sent to recycling centres for processing. Plastics such as HDPE (High-density Polyethylene) or PVC (Polyvinyl Chloride) are recovered, baled and sold as a plastic grade. In particular HDPE, which is used in the manufacture of plastic pipes and drains, can be reprocessed to produce a 're-melt' grade of plastic pellet for use in injection moulding industries within Ireland. Building rubble, which contains materials such as concrete, masonry, and brick, can be crushed on site and reused as backfill material on the site or sent to landfill; generally waste concrete is not sent for recycling as there are few available end markets.

\subsection{Waste Reporting}

In line with construction activity, the level of reported C\&DW collected in Ireland fell by over $80 \%$ from 2007 to 2011. It was estimated that over three million tonnes of C\&DW were collected in Ireland in 2011 (last available figures), with $19 \%$ of this brought to landfill sites, accounting for $28 \%$ of the total weight of material brought to landfill. While the Irish Environmental Protection Agency (EPA) reported that 78\% of C\&DW was recovered, 95\% of that sent to landfill was recovered. Annual figures compiled for C\&DW collected and recovered at landfill sites are gathered through Local Authority, landfill facility and recovery organisation surveys. The annual reports acknowledge that some estimates of tonnes of material managed are unreliable as not all active waste facilities return reports $(17 \%$ in 2011). Data for material in storage at all landfill facilities are not available and waste collection permit holders can fail to properly account for where the waste was collected which may lead to errors in reporting the quantities of waste collected (McCoole, Kurz, McDonagh, O’Neill, \& Derham, 2013).

While these figures appear to show that Ireland is recovering a high proportion of C\&DW, the EPA reports considerable discrepancies between amounts collected and those recovered and disposed of (Table 3). These discrepancies are generally attributed to a lack of reliability of some sources, mainly as a result of poor record keeping by waste facilities and estimated rather than actual figures being supplied by operators (McCoole et al., 2013). Therefore, reported figures for recovery should be treated with caution. It should also be noted that the annual reported figures do not include demolition rubble reused on site.

Table 3. Construction and Demolition Waste Collected and Managed 2004 -2011 (Source: National Waste Statistics - Reports and Bulletins, 2013)

\begin{tabular}{llllllll}
\hline Year & $\begin{array}{l}\text { Waste } \\
\text { Collected (t) }\end{array}$ & $\begin{array}{l}\text { Recovered } \\
(\mathrm{t})\end{array}$ & $\begin{array}{l}\text { Recovered } \\
(\%)\end{array}$ & $\begin{array}{l}\text { Disposal } \\
(\mathrm{t})\end{array}$ & $\begin{array}{l}\text { Disposal } \\
(\%)\end{array}$ & $\begin{array}{l}\text { Discrepancy } \\
(\mathrm{t})\end{array}$ & $\begin{array}{l}\text { Discrepancy } \\
(\%)\end{array}$ \\
\hline 2011 & $3,003,691$ & $2,358,714$ & $78.5 \%$ & 35,404 & $1.2 \%$ & 609,573 & $20.3 \%$ \\
2010 & $3,464,683$ & $2,533,454$ & $73.1 \%$ & 44,621 & $1.3 \%$ & 886,608 & $25.6 \%$ \\
2009 & $5,093,666$ & $5,099,310$ & $100.1 \%$ & 55,926 & $1.1 \%$ & $-61,570$ & $-1.2 \%$ \\
2008 & $13,500,000$ & $10,218,913$ & $75.7 \%$ & 230,228 & $1.7 \%$ & $3,050,859$ & $22.6 \%$ \\
2007 & $17,791,745$ & $12,774,774$ & $71.8 \%$ & 974,934 & $5.5 \%$ & $4,042,037$ & $22.7 \%$ \\
2006 & $16,819,904$ & $13,365,880$ & $79.5 \%$ & 442,567 & $2.6 \%$ & $3,011,457$ & $17.9 \%$ \\
2005 & $14,931,456$ & $12,979,337$ & $86.9 \%$ & 448,425 & $3.0 \%$ & $1,503,694$ & $10.1 \%$ \\
2004 & $11,167,599$ & $9,527,224$ & $85.3 \%$ & 13,262 & $0.1 \%$ & $1,627,113$ & $14.6 \%$
\end{tabular}

a: Compiled figures not available prior to 2004.

\subsection{Recycling of Waste}

Two Irish data sources reported amounts ranging from 2.3 million tonnes in 2005 to 16.6 million tonnes in 2006, with recycling levels of $43 \%$ and $80 \%$ respectively (Environment Directorate-General of the European Commission [European Commission DG ENV], 2011). While the 2006 figure is very similar to that calculated by the EPA, the 2005 estimate differs by over 12.5 million tonnes for waste generated and by $45 \%$ for recycling. The European Commission attributes these differences to inconsistencies in definitions and the composition of 
materials included. In 2011, from figures reported by the EPA (Figure 2), it can be calculated that 67\% of C\&DW collected in Ireland comprised of soil and stone, which can be presumed to be excavated material, with less than $5.5 \%$ of the collected material containing rubble, which normally consists of waste concrete/block. The lack of reliable data and missing records make it extremely difficult to calculate the potential availability of material for recycling, or its fate.

\section{$3.4 C \& D W$ Recycling in the EU}

EU countries, in line with Article 11 of Waste Framework Directive 2008/98/EC, are required to achieve a minimum target of recycling $70 \%$ of non-hazardous C\&DW by 2020 . There are differences in handling, reporting and definitions of both waste and recycling between member states which can make estimating actual recycling rates difficult (European Commission DG ENV, 2011; Directive 2008/98/EC on waste (Waste Framework Directive), 2013). Most of the EU15 countries report C\&DW recycling levels of over $60 \%$ with countries such as Germany, The Netherlands and Denmark achieving high levels of recycled aggregate use (Fischer \& Werge, 2009). In Germany, the material is used almost exclusively in earthworks and road construction (Weil, Jeske, \& Schebek, 2006). At $28 \%$ of total aggregate used in construction, the UK has three times the average use and the highest market share of recycled aggregates in Europe (MPA, 2012; European Environment Agency [EEA], 2008). While a number of factors including the geographic availability of materials (Hicks, 2008) have contributed to this success, an aggregate levy imposed on primary aggregate extraction funds the Waste and Resources Action Programme (WRAP) Aggregates Programme initiative, which aims to promote the use of recycled materials and reduce reliance on primary aggregates (Rates and allowances: Aggregates levy, 2013; WRAP,2013)

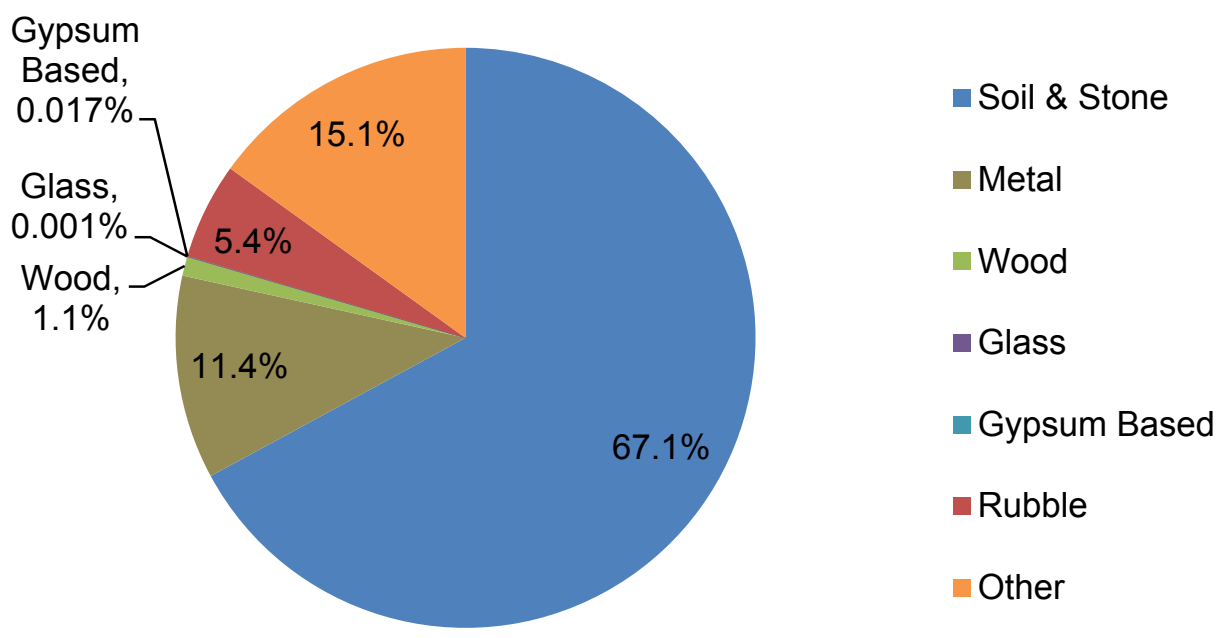

Figure 2. Composition of Construction and Demolition Waste 2011 (Source: McCoole et al., 2013)

\section{Viability of Recycled Aggregate}

To be a viable alternative to natural material, recycled aggregate must offer a cost effective alternative to natural primary material that meets technical requirements while having a lower impact on the environment. Duran, Lenihan, \& O'Regan, (2006) examined the economic viability of creating markets for recycled C\&DW in Ireland, with a proposal to establish three (two fixed and one mobile) recycling centres in major urban areas. They assumed that demolition contractors would bring waste to a recycling centre only if it cost less than disposal at a landfill site. The decision on whether to use recycled aggregate was deemed to be similar in terms of providing a cost advantage, with the additional requirement that the recycled material must be of comparable quality to an equivalent natural aggregate. The authors concluded that to encourage the adoption of recycled aggregates, the cost of using landfill and natural aggregates should include the environmental cost of these activities by way of additional charges and taxes. 


\subsection{The Irish Context}

While it is difficult to verify quarry output figures for Ireland (InterTrade Ireland, 2012), by 2012 output had reduced to just $20 \%$ of estimated capacity (Table 4). Landfill charges have also increased substantially in the intervening years (see section 4.4). In 2011, the Irish Government raised the possibility of introducing an aggregate levy. Unlike the UK, this was not intended as an environmental tax but as a fund for remediation works to those homes affected by pyritic heave (Levy to fund remediation scheme for pyrite homes will provide certainty for homeowners, 2012), however this was not pursued. Given the changes in industry and the lower volumes of C\&DW being generated, the proposal for dedicated recycling facilities may be no longer viable; a possible alternative would be for waste material to be brought to quarries where the necessary machinery, equipment and expertise for processing aggregate already exist.

Concerns of construction materials suppliers with regard to the environmental impacts of their business has resulted in the adoption of industry led environmental codes and the widespread introduction and acceptance of alternative cementitious products intended to reduce the greenhouse gas emissions associated with cement production (Irish Concrete Federation [ICF], 2005a; Sustainable Development, 2013). Despite increasing charges and changing attitudes, the use of recycled aggregate remains low, with the predominant use being backfill following demolition. This may be due to a number of reasons not least the abundant availability of good quality, low-cost primary aggregate, for which demand has fallen considerably in the past few years.

Table 4. Estimated Quarry Output for ROI (Source: Ready Mixed Concrete - Introduction, 2012; Statistics, 2013; InterTrade Ireland, 2012)

\begin{tabular}{llllllllll}
\hline Year & 2005 & 2006 & 2007 & 2008 & 2009 & 2010 & 2011 & 2012 & Current Capacity \\
\hline Tonnes $(\mathrm{m})$ & 176 & 110 & 130 & 50 & 39 & 50 & 32 & 25 & 123 \\
\hline
\end{tabular}

\subsection{Technical Requirements}

In Ireland, the specification, performance, production and conformity of concrete are governed by European standard I.S. EN 206-1:2002 and by the Irish National Annex which provides additional information and guidance. Under Clause 5.1.3 of I.S. EN 206, aggregates for use in concrete production are required to conform to the European standard I.S. EN 12620. However, Clause 5.1.3 also states that 'provisions for recycled aggregates are not yet included in these standards' (National Standards Authority of Ireland [NSAI], 2010). It should be noted that the recently published version of I.S. EN 12620 allows for the use of recycled aggregates with certain caveats, however a revised national guidance document has not yet been published (NSAI, 2013a). While no specific provision is currently made for the use of recycled aggregate in concrete produced in Ireland, the National Annex allows for its use provided that it is 'by agreement of the parties involved on a project by project basis' (NSAI, 2010). This can be interpreted to mean that the specifier, that is, the person or body responsible for establishing the specification for the fresh and hardened concrete, must agree to its use or the producer cannot utilise the material. In the absence of suitable guidance being available in Irish standards, specifiers generally apply requirements as set out in UK standards and guidance documents.

BS 8500-2:2006, the complementary British standard to BS EN 206-1:2000, distinguishes between two different types of recycled aggregate:

- Recycled Concrete Aggregate (RCA), the product of crushed concrete, resulting in a material that consists of the original primary aggregate used in the parent concrete and the hardened cement paste (mortar) that has adhered to it.

- Recycled Aggregate (RA), produced from demolition waste which includes concrete, masonry and asphalt.

The allowable limits of contaminants in coarse aggregates (material $>4 \mathrm{~mm}$ ) by BS 8500 are set out in Table 5 . Due to the wider composition of RA and the greater potential for harmful constituents, the standard limits its use to strengths of no more than C16/20 or 16MPa (Chisholm, 2011). The use of fine recycled aggregate is not covered by the standard but its use is not precluded, provided that it can be demonstrated that there are no deleterious materials present and its use has been agreed (Chisholm, 2011). The standard also places restrictions on the use of RCA to strengths of C40/50 (40MPa) and places a maximum replacement level of $20 \%$ for strengths of $\mathrm{C} 16 / 20$ (16MPa) to C40/50 (40MPa) for designated concrete. Additionally BS 8500 places restrictions on the exposure classes in which concrete manufactured using recycled aggregate can be placed (Chisholm, 2011). BRE Digest 
330 which provides guidance on minimising the risk of damaging alkali-silica reaction in concrete classifies RCA as being 'normally reactive' (non-reactive), whereas it takes a precautionary approach to RA by classifying it as being highly reactive due to the high variability of constituent material (Livesey, 2009). This restriction will limit the use of RA in certain applications.

Recycled aggregate is not one material, but a combination of the original natural aggregate and the mortar that has adhered to it, which has an effect on the mechanical properties of the material such as: water absorption, Los Angeles Abrasion (a measure of abrasion resistance) and modulus of elasticity (de Juan \& Gutiérrez, 2009). The study of the long-term effects of recycled aggregate on these properties is still at a relatively early stage. Though results can be contradictory there are indications that the use of recycled aggregate in the manufacture of concrete has some negative effects, (Xiao, Li, L., Tam, \& Li, H., 2014). Comparative tests have found lower strength gain than conventional concrete; however, estimating this strength loss is difficult as studies have shown varying results (Rahal, 2007; Rakshvir and Barai, 2006; Martínez-Lage, Martínez-Abella, Vázquez-Herrero, \& Pérez-Ordóñez, 2012; Marie \& Quiasrawi, 2012). This has been attributed to poorer mechanical properties, higher water absorption, and increased water demand of recycled aggregate as a result of adhered mortar and more angular shape (Zega, Villagran-Zaccardi, \& Di Maio, 2010; Rakshvir \& Barai, 2006). This could have potentially negative impact on construction schedules, as it may be necessary to delay stripping formwork to allow longer time for strength development. This may be a requirement for additional cement to increase strength (Gonzalez-Fonteboa \& Martınez-Abella, 2008; Etxeberria, Vázquez, Marí, \& Barra, 2007). The use of additives and high-range superplasticisers have also been found to be highly effective in reducing water demand (Richardson, Coventry, \& Bacon, 2011; Zaharieva, Buyle-Bodinb, \& Wirquin, 2004).

Table 5. Requirements for Coarse Recycled Concrete Aggregate and Coarse Recycled Aggregate by \% Weight (Source: Chisholm, 2011)

\begin{tabular}{ccccccc}
\hline $\begin{array}{c}\text { Type of } \\
\text { Aggregate }\end{array}$ & $\begin{array}{c}\text { Max. } \\
\text { masonry } \\
\text { content }\end{array}$ & $\begin{array}{c}\text { Max. } \\
\text { fines }\end{array}$ & $\begin{array}{c}\text { Max. lightweight } \\
\text { material } \\
(<1,000 \mathrm{~kg} / \mathrm{m} 3)\end{array}$ & $\begin{array}{c}\text { Max. } \\
\text { asphalt }\end{array}$ & $\begin{array}{c}\text { Max. glass, } \\
\text { plastic, } \\
\text { wood }\end{array}$ & $\begin{array}{c}\text { Max. } \\
\text { acid-soluble } \\
\text { sulphate }\end{array}$ \\
\hline RCA & 5 & 5 & 0.5 & 5.0 & 1.0 & 1.0 \\
RA & 100 & 3 & 1.0 & 10.0 & 1.0 & $\mathrm{a}$ \\
\hline
\end{tabular}

a: to be determined on a case by case basis.

The University of Dundee examined recycled aggregate (RA) as defined by BS 8500 , finding that the material was suitable for use in concrete and road construction but tended to be highly variable. This variability was dependent on the geological rock type, feed material and the type of processing used (Dhir, Paine, \& Halliday, 2008) as processing affects the amount of adhered mortar and particle shape (Matias, de Brito, Rosa, \& Pedro, 2013; Etxeberria et al., 2007). Recycled aggregates made with lower strength parent concrete and second generation recycled aggregate both produce better results as the crushing process removes more of a weaker mortar than that of a higher strength mix. This results in a higher proportion of natural aggregate in the final product (Tabsh \& Abdelfatah, 2009; Marie \& Quiasrawi, 2012). Care must be taken however when recycled aggregate contains masonry as potential contamination with gypsum can affect the setting time of concrete and potential reactivity may also cause damage to concrete (NSAI, 2013a).

\subsection{Environmental Impacts}

Within the life-cycle of concrete, the first phase of raw material extraction and last one of disposal and recycling are the main contributors to environmental effects (Marinkovic, Radonjanin, Malešev, \& Ignjatovic, 2010; Marie \& Quiasrawi, 2012). Recycling C\&DW as aggregate has been encouraged as a means of reducing environmental impact by reducing natural resource exploitation, transport and energy use in addition to reducing the amount of waste being sent to landfill (Cement Sustainability Initiative [CSI], 2009a).

Aggregates are a non-renewable resource; their extraction requires the resource base to be continuously extended, impacting on land use which in turn impacts on ecosystems, groundwater quality, and biodiversity (Bloodworth, Scott, \& McEvoy, 2009). Although Ireland has the highest agricultural land use cover in Europe, the proportion of land taken by industrial use, which includes quarrying, is almost twice the European average (Land cover, land use and landscape, 2013). Exceptionally, Ireland has plentiful reserves of good quality aggregates that are inexpensive to extract and process. There are currently 1,200 legal aggregate extraction sites in the country (ICF, 2012). In 
comparison, the UK has approximately 1,300 quarries (The quarrying industry, 2013) with a population 13 times greater (Statistics - Population, 2013; Theme: population, 2013). While dust pollution, vibration and noise from quarrying activity are generally relatively low, they can cause nuisance. Problems may also occur from contaminated runoff from storm water, spoil heaps, washing ponds, and fuel spills discharging into water courses, and the de-watering of groundwater caused by excavation below the water table (Department of the Environment, Heritage and Local Government [DoEHLG], 2004). Recycling C\&DW will not completely remove these impacts (Blengini \& Garbarino, 2010) particularly as the processes involved in the production of recycled aggregate are similar to that of natural aggregate production. However, their use can lessen the effect by reducing the frequency of activities such as drilling and blasting, reduced land take, groundwater and dust pollution. Recycling activity may also take place in sensitive locations where extraction would not be permitted.

Concrete is responsible for over $60 \%$ of the embodied energy of the materials used in construction of housing and is responsible for $99 \%$ of $\mathrm{CO}_{2}$ emissions in the construction phase (Ortiz, Castells, \& Sonnemannal, 2009). Of the ingredients used, the greatest environmental impact occurs during the manufacture of cement, which results in approximately one tonne of $\mathrm{CO}_{2}$ produced for every tonne produced, with cement responsible for $5 \%$ of the global production of $\mathrm{CO}_{2}$ (CSI, 2009b). However, once cement is hydrated, it cannot be recovered (CSI, 2009a). Using recycled aggregate will not reduce greenhouse gas emissions from cement production and may in fact potentially result in an increase in cement use to compensate for lower strengths, therefore, increasing environmental impact. However, in a process known as carbonation, $\mathrm{CO}_{2}$ from the atmosphere is reabsorbed into concrete. The rate is dependent on a variety of factors and difficult to measure but it has been estimated that over $50 \%$ of emitted $\mathrm{CO}_{2}$ from cement manufacture will be reabsorbed by concrete over a 100 year period (Engelsen, Mehus, Pade, \& Saether, 2005; Kjellsen, Guimaraes, \& Nilsson, 2005, Dayaram, 2010). It has been determined that the greater surface area of the crushed recycled material allowed for increased carbonation levels, although the rate depend on how long material may be stored prior to reuse and the final use of the material (Engelsen et al., 2005; Kjellsen et al., 2005). The UK Mineral Products Association (MPA) (2012) has looked specifically at how much $\mathrm{CO}_{2}$ is likely to be absorbed during the demolition of a building. They found that following the demolition, separated materials may remain in place for some time prior to reuse. While this may be a very short period in life cycle terms, the exposure of crushed concrete to air for even a few weeks can result in a relatively rapid uptake of $\mathrm{CO}_{2}$ (De Saulles, 2013).

Transport contributes significantly to environmental impacts (Blengini \& Garbarino, 2010). In many countries aggregate sources are located away from urban centres and concrete manufacturing plants, whereas C\&DW is generally generated and recovered in urban areas. The use of recycled aggregates may therefore reduce transport related impacts. There are however, few major urban centres in Ireland outside Dublin and approximately $90 \%$ of concrete manufacturing plants are located in close proximity to their aggregate sources (ICF, 2005b). For Ireland, this would result in a negative environmental impact as the material would require at least one additional journey, traveling from demolition site to a recycling facility for processing. Marinkovic et al. (2010) found that, depending on the distances travelled by materials to manufacturing and construction sites and the relative location of demolition and recycling sites, using recycled aggregates may result in a higher impact on the environment. The MPA also concluded that transporting recycled aggregates distances greater than $15 \mathrm{~km}$ by road resulted in a negative carbon impact compared to using natural aggregate (MPA, 2012). However, Blengini and Garbarino (2010) estimated that transport distances would need to increase considerably above this to negate the positive effects of their use.

\subsection{Economic Considerations}

Recycling must be attractive to both demolition contractors and, aggregate and concrete producers. Assuming that the cost of demolishing a building and the sorting/separation of waste for removal off-site are included in a contract price, the most cost-effective solution for the contractor would be the reuse of the remaining building rubble as backfilling on site without further treatment, after the other materials have been removed. Alternately, the material may need to be processed into smaller fraction sizes for other uses on the site. This would involve the use of a mobile crushing plant, which may typically cost in the region of $€ 4.50$ per tonne to produce. If the material is not required on site, the demolition contactor must arrange for the material to be transported to either a landfill facility or recycling centre. Typical haulage costs per tonne are provided in Table 6 . The main difference in choosing between landfill or recycling is the landfill tax levy and any gate fees that will be incurred. 
Table 6. Typical Haulage Costs per Radial Kilometre (Source: CEMEX Ireland)

\begin{tabular}{llllll}
\hline Radial $(\mathrm{km})$ & $0-10$ & $11-20$ & $20-30$ & $31-40$ & $41-50$ \\
\hline Cost per tonne $(€)$ & 1.80 & 2.50 & 3.40 & 4.30 & 5.20 \\
\hline
\end{tabular}

A levy of $€ 15$ per tonne was introduced in Ireland in 2002 for waste being disposed of at landfill sites, which is payable in addition to any charge from the landfill operator. The purpose of the levy is to 'encourage the diversion of waste away from landfill and generate revenues that can be applied in support of waste minimisation and recycling initiatives' (Landfill levy, 2013). Since then, the levy has increased incrementally to a rate of $€ 75$ per tonne in 2012 (Statutory Instrument [S.I.] 221, 2012).

There are certain exemptions to the levy which include the following categories (S.I. 434, 2011):

- 'Non-hazardous waste from construction and demolition activity, comprising concrete, bricks, tiles, road planings or other such similar materials, with a particle size of $150 \mathrm{~mm}$ or less, which is used for landfill site engineering, restoration or remediation purposes.

- Excavation spoil comprising clay, sand, gravel or stone, which is used for landfill site engineering, restoration or remediation purposes'.

Under Section 4.6 of the EPA Landfill Manual for Operational Practices, 'traditional covers' to landfill are typically composed of 'sub-soils and other excavation wastes or construction industry wastes such as bricks and crushed broken concrete' (EPA, 1997). Additionally, landfill facilities charge a gate fee of between $€ 56$ and $€ 81$ per tonne for inert waste (Typical charge (gate fee and landfill tax) for legal landfilling of non-hazardous municipal waste in EU Member States and regions, 2013). If the material is not taken in as landfill cover, the resulting cost may range from $€ 131$ to $€ 156$ per tonne. In the UK, where the waste is of good quality, for example, uncontaminated high strength concrete, recycling facilities may pay the demolition contractor for the material. However, given the availability of natural aggregate in Ireland, this scenario is unlikely to occur.

In considering whether the use of recycled aggregates would provide a financial benefit to a concrete manufacturer, the costs of buying in already processed material, processing the material in-house and producing natural aggregate must be compared. As many Irish concrete manufacturers use own aggregate sources (ICF, 2005b), buying in processed material from an external supplier and paying additional haulage charges would be unusual, regardless of the internal pricing policy of the company. A more attractive option may be to take in C\&DW for processing. While the processing of C\&DW is essentially the same as that of natural material, there are some differences to consider that will affect the relative merits of both processes. Unlike quarried material, recycling aggregate does not incur blasting and extraction costs and the producer may charge a gate fee for taking in C\&DW material. However, although processes are similar to that of producing natural aggregate, due to the necessity for heavier plant and lower processing rates to produce the material, the cost of crushing and screening C\&DW can be approximately $50 \%$ greater than that of natural aggregate. Additional manpower may also be required for increased quality control checks to prevent contamination and ensure consistency of the feed material. Other cost considerations include waste management permits and the additional costs of increasing cement and admixture use to mitigate for possible loss of strength in concrete mixes. Capital investment may be required to provide additional separate storage areas, to prevent inadvertent use or cross contamination. Concrete batching plant control systems may also need to be modified to allow for use of the material.

\section{Alternative Uses}

Unlike ready-mixed concrete, pre-cast concrete products are manufactured and stored before being supplied to customers, allowing for their properties to be tested and verified before use. Manufactured using a relatively dry mix and generally not required to achieve high strengths, a $100 \mathrm{~mm}$ standard concrete block weighing around $20 \mathrm{~kg}$ will contain approximately $90 \%$ aggregate. A small block plant producing 20,000 standard blocks per day will, on average, use over 80,000 tonnes of aggregate annually. Soutsos, Tang, \& Millard (2011a) examined the potential use of recycled aggregates in standard concrete building blocks, paving blocks, and paving flags, finding that up to $60 \%$ of the coarse fraction could be replaced by recycled concrete aggregate without affecting performance. Initial trials conducted in Ireland have also successfully used recycled aggregate in concrete blocks. However, as with concrete, contamination in recycled aggregate derived from masonry affects strength development (Soutsos et al., 2011a; Soutsos, Tang, \& Millard, 2011b; Soutsos, Tang, \& Millard, 2012).

While the National Road Authority (NRA) in Ireland expressly prohibits the use of recycled aggregates in structural concrete, it is allowed in particular types of unbound materials for road pavement construction and for 
use in capping materials, subject to meeting certain criteria. With the exception of recycled asphalt, recycled aggregate used for capping material must be derived from a construction process, so as to ensure traceability of the materials' origin (NRA, 2013). In Finland, the retained cementitious properties and increased strength of recycled aggregate are recognised, which is utilised to either increase the load bearing capacity of the road or to allow for thinner road layers and reduced material use (CSI, 2009b; Vyncke, 2000). EN 13450:2013, the European standard governing aggregates for railway ballast allows for the use of recycled aggregate from C\&DW provided the material meets the requirements set out in the standard (NSAI, 2013b). Due to the higher water absorption observed in recycled aggregates and the effect on durability, the materials may require testing on a case by case basis to assess suitability. Due to concerns following recent pyrite controversy and to avoid the risk of possible contamination, the use of recycled aggregate is prohibited from use as hardcore under concrete floors and footpaths in Ireland (NSAI, 2014)

Alternatively, research published by De Schepper, De Buysser, Van Driessche, \& De Belie (2013) put forward the development of completely recyclable concrete (CRC) to overcome difficulties in the acceptance of recycled aggregate. The concept proposes that concrete should be designed to have a similar chemical composition to cement raw materials, enabling the material at the end of its life to become a valuable resource for cement production rather than a waste.

\section{Conclusion}

Like many countries, Ireland is facing the problem of what to do with large areas of unoccupied housing. The clearance of these sites leaves the problem of how best the waste material may be reused. Ireland reports consistently high levels of C\&DW recycling, yet evidence suggests low levels of recycled aggregate use. This is in part because of the low incentive for use resulting from the widespread availability of high quality, low cost primary material throughout the country.

In terms of costs, the recycling process is similar to that of producing natural aggregate without incurring extraction costs. Advantage may be also gained from charging a gate fee that could increase the contribution to the producer's aggregate business and offset additional manpower, processing, licencing and testing costs. However, investment in additional plant and control systems may be necessary.

Using recycled aggregates also has advantages in conserving resources and has strong merits in terms of reducing impact on land, water resources and the local environment. Conversely, its use could lead to other impacts such as higher cement use to compensate for strength loss and in particular, from additional transport requirements, which must be considered.

The use of recycled aggregate could provide economic benefit that has less impact on the environment than processing natural aggregate. While recycled aggregate is used in many projects, its use in manufacturing ready-mixed concrete remains difficult in both meeting regulatory requirements and in gaining acceptance. This is very much evident in the UK, where despite supports and incentives in place, its use in concrete manufacture is still not widespread. While much research has been conducted into suitability testing and changing current specification methods, the industry recognises that market demand is more likely to be a driver of increasing use than specifically targeted programmes (MPA, 2012; Dhir and Paine, 2007). With difficulties in achieving significant replacement levels in concrete manufacture in countries where support mechanisms and incentives for use exist, a particular issue may also hamper efforts to encourage greater use in Ireland as following the pyrite contamination issues of the recent past; specifiers are unlikely to approve the use of recycled aggregate without reassurance of quality and performance.

There are many other options available for recycled aggregates produced from C\&DW. The material has been shown to perform satisfactorily in lower grade products, where some of the problems associated with use of the material for structural concrete may not be encountered and may even provide enhanced performance when compared to natural aggregate. Also, the cost of producing material suitable for use in manufacturing pre-cast products and road-base construction is generally lower than that required for ready-mixed concrete.

Natural aggregate is a non-renewable finite resource and research in Ireland into the use of recycled aggregate lags far behind many other European countries. Gaining acceptance in an unsupportive regulatory and commercial environment will be extremely difficult. Lessons can be learned from measures to increase adoption rates in other countries, such as banning the recyclable part of C\&DW from landfill in the Flanders region of Belgium and The Netherlands (Tojo, 2010; Bohmer et al., 2008). In particular the aggregate levy in the UK, while unpopular, has been used successfully to provide information and support to industry, in commissioning research into greater use of recycled aggregates and in addressing restrictions placed on the use of the material (MPA, 2012; Dhir and Paine, 2007). 
With high quality, strong natural aggregate used in the parent material production and little research conducted to date in Ireland, it is necessary to assess how this material behaves when used to produce a recycled aggregate. An extraction levy could fund such research to inform product and to provide necessary reassurance to specifiers and producers while encouraging adoption in the market as taxation is ultimately borne by the end user.

\section{Acknowledgements}

The authors wish to thank the following for providing financial and industry specific information: CEMEX Ireland, Roadstone Ltd., Irish Concrete Federation, Padraig Arthur \& Associates, National Construction and Demolition Waste Council, Irish Packaging Recycling Ltd, Hegarty Demolition, and Day Group (UK).

\section{References}

Blengini, G. A., \& Garbarino, E. (2010). Resources and waste management in Turin (Italy): the role of recycled aggregates in the sustainable supply mix. Journal of Cleaner Production, 18(10-11), 1021-1030. http://dx.doi.org/10.1016/j.jclepro.2010.01.027

Bloodworth, A. J., Scott, P. W., \& McEvoy, F. M. (2009). Digging the backyard: mining and quarrying in the UK and their impact on future land use. Land Use Policy, 26(1), S317-S325. http://dx.doi.org/10.1016/j.landusepol.2009.08.022

Bohmer, S., Moser, G., Neubauer, C., Peltoniemi, M., Schachermayer, E., Tesar, M., ... Winter, B. (2008). Aggregates case study, final report. Contract No.150787-2007 F1SC-AT Commissioned by the Institute for Prospective Technological Studies. Retrieved from: http://www.sarmaproject.eu/uploads/media/JRC_ Aggregates_FinalRep_UBA_080331.pdf

Cement Sustainability Initiative. (2009a). Recycling concrete. World Business Council for Sustainable Development Cement Sustainability Initiative. Retrieved from http://www.wbcsdcement.org/index.php/ publications

Cement Sustainability Initiative. (2009b). Cement industry energy and $\mathrm{CO}_{2}$ performance: Getting the numbers right. World Business Council for Sustainable Development Cement Sustainability Initiative. Retrieved from http://www.wbcsdcement.org/index.php/publications

Central Statistics Office. (2008). Construction and housing in Ireland. Published by the Stationery Office, Dublin on behalf of the Central Statistics Office, Information Section, Skehard Road, Cork, Ireland.

Central Statistics Office. (2013). Sustainable development indicators report 2013. Published by the Stationery Office, Dublin on behalf of the Central Statistics Office. Information Section, Skehard Road, Cork, Ireland.

Chisholm, D. (2011). TR 14 Best practice guide for the use of recycled aggregates in new concrete. Published by Cement and Concrete Association of New Zealand. Retrieved from http://www.ccanz.org.nz/documents.aspx

Construction Industry Federation (2013). CIF housing statistics bulletin. CIF, Construction House, Canal Road, Dublin 6, Ireland. Retrieved from: http://cif.ie/images/Housing-Stats-Bulletin-April-2013.pdf

Dayaram, K. (2010). The recarbonation of crushed concrete from a New Zealand perspective (Master's Thesis, University of Canterbury, New Zealand). Retrieved from http://ir.canterbury.ac.nz/bitstream/10092/3859/1/ KiranDayaramMastersThesis.pdf

de Juan, M. S., \& Gutiérrez, P. A. (2009). Study on the influence of attached mortar content on the properties of recycled concrete aggregate. Construction and Building Materials, 23(2), 872-877. http://dx.doi.org/10. 1016/j.conbuildmat.2008.04.012

De Saulles, T. (2013). Carbonation from an environmental perspective. Concrete, April:54-55 Retrieved from http://www.concretecentre.com/sustainability/end_of_life_recycling/carbonation_of_concrete.aspx

De Schepper, M., De Buysser, K., Van Driessche, I., \& De Belie, N. (2013). The regeneration of cement out of completely recyclable concrete: clinker production evaluation. Construction and Building Materials, 38, 1001-1009. http://dx.doi.org/ 10.1016/j.conbuildmat.2012.09.061

Department of the Environment, Heritage and Local Government. (2011). Green tenders: An action plan on green public procurement. Published by the Department of the Environment, Community and Local Government and the Department of Public Expenditure and Reform. Retrieved from http://www.procurement.ie/ publications 
Department of the Environment, Heritage and Local Government. (2004). Quarries and ancillary activities: guidelines for planning authorities. Published by the Department of the Environment, Heritage and Local Government, Customs House, Dublin 1, Ireland.

Dhir, R. K., \& Paine, K. A. (2007). Performance related approach to use of recycled aggregates. Published by Waste \& Resources Action Programme, The Old Academy, 21 Horse Fair, Banbury, Oxen, OX16 0AH, England.

Dhir, R. K., Paine, K. A., \& Halliday, J. E. (2008). Facilitating the wider use of coarse and fine recycled aggregates from washing plants. Conducted by Concrete Technology Unit, Division of Civil Engineering, University of Dundee. Published by Waste \& Resources Action Programme (WRAP) The Old Academy, 21 Horse Fair, Banbury, Oxon OX16 0AH, England.

Directive 2008/98/EC on waste (Waste Framework Directive). (2013). In European Commission Environment. Retrieved May 30, 2013, from http://ec.europa.eu/environment/waste/framework/

Duggal, S. K. (2012) Building Materials, New Age International, 7/30 A, Darya Ganj, New Delhi-110 002, India.

Duran, X., Lenihan, H., \& O’ Regan, B. (2006). A model for assessing the economic viability of construction and demolition waste recycling - the case of Ireland. Resources, Conservation and Recycling, 46(3), 302-320. http://dx.doi.org/ 10.1016/j.resconrec.2005.08.003

EEA. (2008). Effectiveness of environmental taxes and charges for managing sand, gravel and rock extraction in selected EU countries. European Environment Agency EEA Report No 2/2008. European Environment Agency, Kongens Nytorv 6, 1050 Copenhagen K, Denmark. Retrieved from http://www.eea.europa.eu/ publications/eea_report_2008_2

Engelsen, C. J., Mehus, J., Pade, C., \& Saether, D. H. (2005). Carbon dioxide uptake in demolished and crushed concrete. Project Report 395, Nordic Innovation Centre Project 03018. Norwegian Building Research Institute, Forskningsveien 3 B, Postboks 123 Blindern, N-0314, Oslo, Norway.

Environmental - Overview. (2013). In ECOCEM. Retrieved March 09, 2013, from http://www.ecocem.ie/environmental.htm

Environmental Protection Agency. (1997). Landfill manuals: landfill operational practices. Published by the Environmental Protection Agency, Ardcavan, Wexford, Ireland.

Etxeberria, M., Vázquez, E., Marí, A., \& Barra, M. (2007). Influence of amount of recycled coarse aggregates and production process on properties of recycled aggregate concrete. Cement and Concrete Research, 37(5), 735-742. http://dx.doi.org/10.1016/j.cemconres.2007.02.002

European Aggregates Association. (2012). Annual review 2011-2012. European Aggregates Association, Rue d' Arlon 21 - 1050 Brussels, Belgium. Retrieved from http://www.uepg.eu/uploads/Modules/Publications/ uepg---ar2012---en_v1.pdf

European Commission DG ENV. (2011). Service contract on management of construction and demolition waste SR1. Final report task 2. Prepared by BIO Intelligence Service in association with ARCADIS and IEEP (Institute for European Environmental Policy). Retrieved from: http://ec.europa.eu/environment/waste/ construction_demolition.htm

Finnegan, M., Maloney. S., \& Duffy, T. (2012). Irish residential market: review 2012 / outlook 2013. Retrieved from http://www.sherryfitz.ie/resi/buy/marketreports.aspx

Fischer, C., \& Werge, M. (2009). Europe as a recycling society, present recycling levels of municipal waste and construction \& demolition waste in the EU. Prepared for the European Environment Agency by the European Topic Centre on Resource and Waste Management. European Topic Centre on Sustainable Consumption and Production, Højbro Plads 4, DK-1200 Copenhagen, Denmark.

Gonzalez-Fonteboa, B., \& Martınez-Abella, F. (2008). Concretes with aggregates from demolition waste and silica fume. Materials and mechanical properties. Building and Environment, 43(4), 429-437. http://dx.doi.org/10.1016/j.cemconres.2007.02.002 10.1016/j.buildenv.2007.01.008

Hicks, L. (2008). Aggregates supply in England: Issues for planning. British Geological Survey Open Report OR/08/059. Published for the Department of Communities and Local Government, British Geological Survey, Keyworth, Nottingham, NG12 5GG, England. 
Housing Agency (2012). National housing development survey summary report. Published by Housing Agency and Department of the Environment, Community and Local Government. Retrieved from http://www.housing.ie/Our-Services/Unfinished-Housing-Developments/2012-National-Housing-Survey

InterTrade Ireland. (2012). Report on a competitive analysis of the construction materials sector in Ireland. Published by The Trade and Business Development Body, The Old Gasworks Business Park, Kilmorey Street, Newry, Co Down, BT34 2DE, Northern Ireland.

Irish Concrete Federation. (2005a). Irish Concrete Federation environmental code, 2nd edition. Published by the Irish Concrete Federation, 8 Newlands Business Park, Naas Road, Dublin 22, Ireland.

Irish Concrete Federation. (2005b). Concrete products directory (3rd ed.). Published by the Irish Concrete Federation, Unit 8 Newlands Business Park, Dublin 22, Ireland.

Kjellsen, K. O., Guimaraes, M., \& Nilsson, A. (2005). The $\mathrm{CO}_{2}$ Balance of Concrete in a life cycle perspective. Nordic Innovation Centre, Stensberggata 25, NO-0170 Oslo, Norway.

Land cover, land use and landscape. (2013). In European Commission Eurostat. Retrieved July 17, 2013, from http://epp.eurostat.ec.europa.eu/statistics_explained/index.php/Land_cover,_land_use_and_landscape

Landfill levy. (2013). In Environment, Community and Local Government. Retrieved June 8, 2013, from http://www.environ.ie/en/Environment/Waste/LandfillLevy/

Levy to fund remediation scheme for pyrite homes will provide certainty for homeowners. (2012). In Environment, Community and Local Government. Retrieved May 5, 2013, from http://www.environ.ie/en/DevelopmentHousing/BuildingStandards/News/MainBody,32071,en.htm

Livesey, P. (2009). BRE Digest 330: alkali-silica reaction in concrete - the case for revision Part II. Concrete, 43(7), 35-36.

Marie, I., \& Quiasrawi, H. (2012). Closed-loop recycling of recycled concrete aggregates. Journal of Cleaner Production, 37, 243-248. http://dx.doi.org/10.1016/j.jclepro.2012.07.020

Marinkovic, S., Radonjanin, V. Malešev, M., \& Ignjatovic, I. (2010). Comparative environmental assessment of natural and recycled aggregate concrete. Waste Management, 30(11), 2255-2264. http://dx.doi.org/10.1016/j.wasman.2010.04.012

Martínez-Lage, I., Martínez-Abella, F., Vázquez-Herrero, C., \& Pérez-Ordóñez, J. L. (2012). Properties of plain concrete made with mixed recycled coarse aggregate. Construction and Building Materials, 37, 171-176. http://dx.doi.org/10.1016/j.conbuildmat.2012.07.045

Matias, D., de Brito, J.A. Rosa, A., \& Pedro, D. (2013). Mechanical properties of concrete produced with recycled coarse aggregates - influence of the use of superplasticizers. Construction and Building Materials, 44, 101-109. http://dx.doi.org/10.1016/j.conbuildmat.2013.03.011

McCoole, F., Kurz, Dr. I., McDonagh, M., O’Neill, D., \& Derham, J. (2013). National waste report for 2011. Environmental Protection Agency, PO Box 3000, Johnstown Castle Estate, County Wexford, Ireland.

Metals Recycling. (2013). In $K M K$. Retrieved July 7, 2013, from http://www.kmk.ie/metal-recycling

Mineral Products Association. (2011). Specifying sustainable concrete. Published by the Mineral Products Association. Retrieved from http://www.concretecentre.com/online_services/publication_library/ publication_details.asp $x$ ?PublicationId $=758$

Mineral Products Association. (2012). Concrete industry sustainability performance report. 5th report: 2011 performance data. Published by MPA, The Concrete Centre, on behalf of the Sustainable Concrete Forum. Retrieved from: http://www.sustainableconcrete.org.uk/top_nav/concrete_sustainable_strategy.aspx

National Roads Authority. (2013). Manual of contract documents for road works: Volume 1 specification for road works. Published by National Roads Authority, St. Martin's House, Waterloo Road, Dublin 4, Ireland.

National Standards Authority of Ireland. (2010). I.S. EN 206-1:2002 Concrete - Part 1: Specification, performance, production and conformity + National Annex $(N A+2)$. Published by the National Standards Authority of Ireland, 1 Swift Square, Northwood, Santry, Dublin 9, Ireland.

National Standards Authority of Ireland. (2013a). I.S. EN 12620:2013 Aggregates for concrete. Published by the National Standards Authority of Ireland, 1 Swift Square, Northwood, Santry, Dublin 9, Ireland.

National Standards Authority of Ireland. (2013b). I.S. EN 13450:2013 Aggregates for railway ballast. Published by the National Standards Authority of Ireland, 1 Swift Square, Northwood, Santry, Dublin 9, Ireland. 
National Standards Authority of Ireland. (2014). S.R. 21:2014 Guidance on the use of I.S. EN 13242:2002+A1:2007. Published by the National Standards Authority of Ireland, 1 Swift Square, Northwood, Santry, Dublin 9, Ireland.

National Waste Statistics - Reports and Bulletins. (2013). In EPA Environmental Protection Agency. Retrieved May 17, 2013, from http://www.epa.ie/pubs/reports/waste/stats/

Ortiz, O., Castells, F., \& Sonnemann, G. (2009). Sustainability in the construction industry: A review of recent developments based on LCA. Construction and Building Materials, 23(1), 28-39. http://dx.doi.org/10.1016/ j.conbuildmat.2007.11.012

Rahal, K. (2007) Mechanical properties of concrete with recycled coarse aggregate. Building and Environment, 42(1), 407-415. http://dx.doi.org/10.1016/j.buildenv.2005.07.033

Rakshvir, M., \& Barai, S. V. (2006) Studies on recycled aggregates-based concrete. Waste Management and Research, 24(3), 225-233. http://dx.doi.org/10.1177/0734242X06064820

Rates and allowances: Aggregates levy. (2013). In GOV.UK. Retrieved June 6, 2013, from http://www.hmrc.gov.uk/rates/agg-levy.htm

Ready Mixed Concrete - Introduction. (2012). In Irish Concrete Federation, set for life. Retrieved November 28, 2012, from http://www.irishconcrete.ie/readymixedconcrete.html?linkidentifier=id\&itemid $=52$

Richardson, R., Coventry, K., \& Bacon, J. (2011) Freeze/thaw durability of concrete with recycled demolition aggregate compared to virgin aggregate concrete. Journal of Cleaner Production, 19(2-3), 272-277. http://dx.doi.org/10.1016/j.jclepro.2010.09.014

Soutsos, M. S., Tang, K., \& Millard, S. G. (2011). Concrete building blocks made with recycled demolition aggregate. Construction and Building Materials, 25(2), 726-735. http://dx.doi.org/10.1016/ j.conbuildmat.2010.07.014

Soutsos, M. S., Tang, K., \& Millard, S. G. (2011b). Use of recycled demolition aggregate in precast products, phase II: Concrete paving blocks. Construction and Building Materials, 25(7), 3131-3143. http://dx.doi.org/10.1016/j.conbuildmat.2010.12.024

Soutsos, M. S., Tang, K., \& Millard, S.G. (2012). The use of recycled demolition aggregate in precast concrete products, phase III: Concrete pavement flags. Construction and Building Materials, 36, 674-680. http://dx.doi.org/10.1016/j.conbuildmat.2012.06.045

Statistics - Population. (2013). In CSO, Central Statistics Office. Retrieved July 8, 2013, from $\mathrm{http}: / /$ www.cso.ie/en/statistics/population/

Statistics. (2013). In UEPG. Retrieved May 19, 2013, from http://www.uepg.eu/statistics

Statutory Instrument No 221. (2012). Waste management (landfill levy) (amendment) regulations 2012. Statutory Instruments published by the Stationary Office, Government Publication Sales Office, Sun Alliance House, Molesworth Street, Dublin 2, Ireland.

Statutory Instrument No 434. (2011). Waste management (landfill levy) regulations 2011. Statutory Instruments published by the Stationary Office, Government Publication Sales Office, Sun Alliance House, Molesworth Street, Dublin 2, Ireland.

Sustainable Aggregates. (2013). In WRAP. Retrieved June 17, 2013, from http://aggregain.wrap.org.uk/sustainable_2.html

Sustainable Development. (2013). In Irish Cement. Retrieved March 9, 2013, from http://www.irishcement.ie/sustainable-development

Tabsh, S. W., \& Abdelfatah, A. S. (2009). Influence of recycled concrete aggregates on strength properties of concrete. Construction and Building Materials, 23(2), 1163-1167. http://dx.doi.org/10.1016/j.conbuildmat. 2008.06.007

The quarrying industry. (2013). In BAA British Aggregates Association. Retrieved June 26, 2013, from http://www.british-aggregates.co.uk/about/quarrying.html

Theme: population. (2013). In UK National Statistics. Retrieved July 8, 2013, from http://www.statistics.gov.uk/hub/population 
Tojo, N. (2010). Europe as a recycling society: recycling policies for selected waste streams in EEA member countries. ETC/SCP working paper 6/2010, European Topic Centre on Sustainable Consumption and Production, Højbro Plads 4, DK-1200, Copenhagen, Denmark.

Typical charge (gate fee and landfill tax) for legal landfilling of non-hazardous municipal waste in EU Member States and regions. (2013). In European Environment Agency. Retrieved June 26, 2013, from

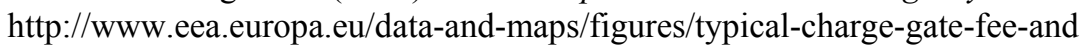

Voluntary Construction Industry Initiative. (2013). In NCDWC National Construction and Demolition Waste Council. Retrieved May 17, 2013, from http://www.ncdwc.ie/html/VoluntaryIndustryInitiative.html

Vyncke, J (Ed). (2000). Use of recycled materials as aggregates in the construction industry. Published on behalf of the European Thematic Network on the Use of Recycled Aggregates in the Construction Industry. ETN Recycling in Construction, c/o WTCB-CSTC, attn. of Mrs. M. Merckx, rue de la Violette, 21-23, B1000 Brussels, Belgium Retrieved from: http://www.eco-serve.net/uploads/ETN_NL2.pdf

Waste and Resources Action Programme. (2013). WRAP aggregates programme. WRAP, The Old Academy, 21 Horse Fair, Banbury, Oxon OX16 0AH, UK. Retrieved from: http://www2.wrap.org.uk/downloads/WRAP Aggregates_Programme_2_.55c9453f.4078.pdf

Waste Licensing \& Permitting. (2013). In EPA Environmental Protection Agency. Retrieved June 8, 2013, from http://www.epa.ie/pubs/legislation/waste/licpermit/\#.VFir6TSsXTo

Waste Mgmt Acts. (2013). In Environment, Community and Local Government. Retrieved June 8, 2013, from http://www.environ.ie/en/Environment/Waste/WasteMgmtActs/

Weil, M., Jeske, U., \& Schebek, L. (2006). Closed-loop recycling of construction and demolition waste in Germany in view of stricter environmental threshold values. Waste Management \& Research, 24(3), 197-206. http, //dx.doi.org/10.1177/0734242X06063686

Xiao, J., Li, L., Tam, V.W.Y., \& Li, H. (2014). The state of the art regarding the long-term properties of recycled aggregate concrete. Structural Concrete, 15(1), 3-12. http://dx.doi.org/10.1002/suco.201300024

Zaharieva, R., Buyle-Bodinb, F., \& Wirquin, E. (2004). Frost resistance of recycled aggregate concrete. Cement and Concrete Research, 34(10), 1927-1932. http, //dx.doi.org/10.1016/j.cemconres.2004.02.025

Zega, C. J., Villagran-Zaccardi, Y. A., \& Di Maio, A. A. (2010). Effect of natural coarse aggregate type on the physical and mechanical properties of recycled coarse aggregates. Materials and Structures, 43(1-2), 195-202. http://dx.doi.org/10.1617/s11527-009-9480-4

\section{Copyrights}

Copyright for this article is retained by the author(s), with first publication rights granted to the journal.

This is an open-access article distributed under the terms and conditions of the Creative Commons Attribution license (http://creativecommons.org/licenses/by/3.0/). 